\title{
The Use of Social Media for Blended Learning in Tertiary Education
}

\author{
Winslet Ting Yan Chan, Chi Hong Leung* \\ Department of Management and Marketing, The Hong Kong Polytechnic University, China
}

Copyright $(2016$ by authors, all rights reserved. Authors agree that this article remains permanently open access under the terms of the Creative Commons Attribution License 4.0 International License

\begin{abstract}
The use of social media facilitates communication and collaboration among users to support the student-centered learning environment. In this study, Twitter was used to support blended learning activities in two university courses. A survey was conducted and the results showed that Twitter was easy to use and it could facilitate knowledge sharing among different learners. However, the text-based communication for a relatively simple exchange hindered the interaction among learners. Moreover, students preferred using social media such as Facebook with a higher degree of popularity.
\end{abstract}

Keywords Social Media, Blended Learning, Twitter, Users' Attitudes

\section{Introduction}

Online learning is pervading tertiary education, which compels educational practitioners to deal with the current assumptions and practices of learning and teaching. At one end of the learning continuum, educators conduct lectures without using the information technology in the physical classroom. Such face-to-face learning approach has been criticized as the least student-centered learning approach. Educators determine what the learners will learn, how they will learn, and how their performance will be evaluated. Face-to-face learning method provides students with less autonomy and flexibility for learning, hindering the development of lifelong learning and independent problem solving skills of students. At the other end of learning continuum, educators conduct lectures on the Internet without classroom teaching and face-to-face meetings, also known as e-learning and fully online learning method. Although e-learning method provides flexibility and time for learning as well as the reality of unbounded educational discourse, it has been considered as applying them merely for the sake of technology [7, 28, 45]. Educators are urged to meet the increasing demands and expectations for superior quality of learning results and experiences. To do so, practitioners are increasingly adopting blended learning, which utilizes and integrates the asynchronous (i.e., text-based Internet) with synchronous (i.e., face-to-face) learning experiences. Blended learning is a pedagogical mode that integrates the strengths of the traditional classroom environment in the physical world and the Internet learning activities in the virtual learning environment $[1,39$, 41].

Learning in the context of social media has become an integral part of the academic experience [20]. Social media are defined as a variety of online applications that develop on the technological and ideological basics of Web 2.0. These Internet-based applications facilitate human communication, interaction, and collaboration by allowing exchange and creation of user-generated content [9]. Various recent studies revealed that students have steadily increased the use of social media for communication, creative expression, and coursework-related collaboration [44]. Other studies showed that educational institutions are progressively implementing social media to support learning and teaching activities [21, 9]. Although there are various types of social media, some are markedly used for educational purposes [20]. For example, wikis are used to engage students in collaborative projects. Wikis are web sites that enable students to develop the written content, construct hyperlinks with information, and modify the content through the addition, deletion or substitution of any portions they want [51]. Social network sites (SNS) (e.g., Facebook) are other social media tools that are useful for educational purpose. In particular, Facebook provides a platform for social networking, facilitating asynchronous and synchronous communication in an informal way. Such informality encourages more interaction among students and teachers. Facebook also enables students to express their ideas in and after class and helps students to formulate their thoughts with the support of multimedia contents such as pictures, videos, and hyperlinks to other URLs [18, 34]. Media sharing tools (e.g., Flickr and YouTube) are frequently used in the education context. Students are encouraged to discuss and ask questions based on the video contents as well as to prepare and upload their videos for information sharing [26]. In addition, blogging 
platforms (e.g., Word Press) are used for the establishment of online portfolios. Likewise, micro-blogging platforms (e.g., Twitter) are used to stimulate student engagement in the classroom. In particular, Twitter enables students to share their thoughts about a discussion topic within 140 characters $[13,31,32,47]$.

Constructivist theory made an important contribution to education in the past 50 years, shaping the way we consider the functional roles of the learner mind and the optimization of knowledge acquisition. Constructivist theory emphasizes the importance of deep learning and acquiring learning strategies or methods used to aid knowledge acquisition [50]. Alongside the rapid development of the information technologies, the current education paradigm is usually regarded as a constructivist paradigm with emphasis on student-centered learning and teachers act as facilitators. In particular, social media contribute to the constructivist paradigm in three ways. First, social media have the capability of storing and manipulating a considerable amount of information in multimedia formats, which enables learners to perform complicated computations and communicate with teachers and other students. Second, while student-centered learning puts emphasis on the significant role of learners in construction of meaning from new knowledge and existing experience. Social media provide a personal learning environment that empowers learners to be responsible for their own ways of learning, and prompt learners to choose resources and tools to construct, manage, and tailor made learning materials to learn efficiently and effectively. Third, social media form a community or provide social learning space that allows learners to create, organize, and share content. Students are able to gather and share resources, create collective knowledge, and make their own meaning $[10,16]$.

This paper therefore discusses the use of social media in particular Twitter for blended learning. Specifically, this paper aims to discuss how Twitter can be used to enhance traditional face-to-face and online learning experiences and explore students' attitude towards the use of Twitter for blended learning in two university courses. At the end of the course, a survey was conducted to collect the feedback from students to explore if such a blending learning mode is practical and beneficial in higher education. This paper also suggests ways for further improvement of using social media in blended learning.

\section{Application of Social Media in Tertiary Institutions}

Popularity of social media draws attention of educational researchers and the use of social media (such as Facebook, blogs and Twitter) in the tertiary educational context has been studied. The following are examples of research that showed students' positive attitudes towards social media used in tertiary institutions.

Rambe [40] studied Facebook posts in a university course and found that more students communicated administrative type posts and concluded that teachers should involve learners in critical engagement, instead of allowing students to receive teachers' content passively. Irwin et al. [24] studied four university courses using Facebook and 78\% of the students thought Facebook was an effective learning tool that enhanced discussion, interaction and access of posted assessments and lecture notes. McCarthy [33] found that $95 \%$ of students in the survey agreed that Facebook assisted them in the development of peer relationships and appreciated the collaborative discussion in the online environment. Kabilan, Ahmad and Abidin [27] revealed that about $70 \%$ of university students using Facebook had positive attitude towards learning and felt the use of social network could motivate learning. Ophus and Abbitt [37] performed a survey in a university course in which Facebook was used to facilitate sharing among students and $95.5 \%$ of students felt communication with others was improved.

Top [48] examined the sense of community including blogging in a university course and indicated that respondents had moderately felt the sense of community, and perceived learning had a stronger relationship with the sense of community. Deng and Yuen [14] revealed that self-refection, self-expression, social interaction could be supported by blogs that sustained students' sense of togetherness and reflected their own practices. Deed and Edwards [12] studied the behaviors of 400 university students using an unrestricted blog and concluded that generally students accomplished the assignments with an unrestricted blog efficiently. Huang, Huang and $\mathrm{Yu}$ [22] examined the effects of using blogs in a university course and found $79 \%$ of the students agreed that they did not feel pressure to use blogs to present their thoughts. Sim and Hew [43] conducted a review on the use of blogs in higher educational environment and found that students liked to use blogs for formative purposes particularly.

Junco, Heiberger and Loken [25] compared the engagement scores two groups of university students and found that the group using Twitter has higher engagement scores than the one without the usage of Twitter. It was suggested that Twitter could improve better contacts between teachers and students and prompt feedback and active learning could be promoted. Dunlap and Lowenthal [17] integrated Twitter into a university course and found the advantage of Twitter over traditional teaching methods was enhancement of social presence. In addition, Twitter could support connection with a professional community of practices and informal teaching and learning. Borau et al. [6] explained the experiences of using Twitter in a language course in the university and found that $70 \%$ of the students agreed that effective language skills could be developed with Twitter.

\section{Use of Twitter in Classroom}

Two-way and real time communication is important in 
teaching and learning activities. However, most students do not like to participate in communication activities such as group discussion and answering questions in the classroom because they consider the communication situation as relatively unrewarding or unexciting. Nowadays, students feel less interested in traditional face-to-face communication and turn to the cyberspace as an alternative communication channel. Such problems can be resolved by using social media such as Twitter to facilitate communication between teachers and students.

Twitter is a free Web 2.0 application and has become a popular micro-blogging and SNS among young people [30]. Twitter facilitates communication among teachers and students by enabling them to exchange tweets that are instant, recurrent, and short messages with the limited length of 140 characters. Twitter also enables teachers and students to update their current status, provide hyperlinks to multimedia, more extensive blogs, and other web resources. There are various ways of using Twitter in the classroom $[8,19]$. In a lecture, students may post questions on Twitter which keeps a running stream of questions. The lecturer may select and answer questions at the end of the lecture. In addition, the lecturer may post revision questions (e.g., asking students to give a definition of a given term) on Twitter during the lecture and ask students to respond to these questions online. Moreover, the lecturer may use Twitter to gather information and feedback from their students (e.g., what activities the students prefer to do or students' opinions on teaching and learning activities) for improving the content of teaching materials. In addition, on the communication between lecturer and students, Twitter can enhance communication or social networking among students. For example, audience (i.e., other students) may post their questions or feedback during the Q\&A session after a presentation delivered by a student. In fact, the discussion activities in the classroom can be continued after class in a virtual environment. Students may write micro reviews of the different discussion topics at their own time through the use of Twitter. Besides, Twitter is also useful for administrative functions. The lecturer may send reminder of upcoming due dates to students and set up a feed dedicated to due dates or tests. Furthermore, the lecturer may use Twitter to coordinate assignments. Rather than using emails, students can utilize Twitter to cooperate with peers in various group works and maintain a rapid reference on any modifications.

Because of the simple text-based communication, Twitter is usually adopted to facilitate relatively low order thinking learning activities (e.g., asking students to remember and understand World War I by sharing the facts and histories online). However, with a thoughtful pedagogical design, it can be used to support and implement learning activities that require higher order thinking skills to be accomplished (e.g., posting a picture about World War I and asking students to evaluate the competiveness of countries involved in World War I). Development of higher order thinking skills is considered basis to education and a fundamental competency for graduating students who think critically and make decisions to solve problems [35]. A student with higher order thinking skills is able to deal with problems in daily life, adapt to the changing world and contribute to society. Bloom's revised taxonomy [2] is one of the most familiar definitions of thinking and it is widely applied in designing educational training and learning processes, which promotes higher order of thinking in education to apply, analyze and evaluate the procedures, processes, concepts and principles, instead of just remembering and understanding the facts. Bloom's revised taxonomy presents six major categories of cognitive objectives in learning processes, starting from the remembering, understanding, applying, analyzing, evaluating, to creating. The categories can be thought of as degrees of difficulties. Specifically, the first category (e.g., remembering) must be mastered before the next category (e.g., understanding) can take place. Table 1 provides examples of how Twitter can be used to support learning activities that require skills ranging from low order thinking to high order thinking. As an example, Table 2 also demonstrates how to achieve the learning objectives of a subject "Integrated Marketing Communications" with Twitter. 
Table 1. Examples of the use of Twitter to support low- and high order thinking learning activities

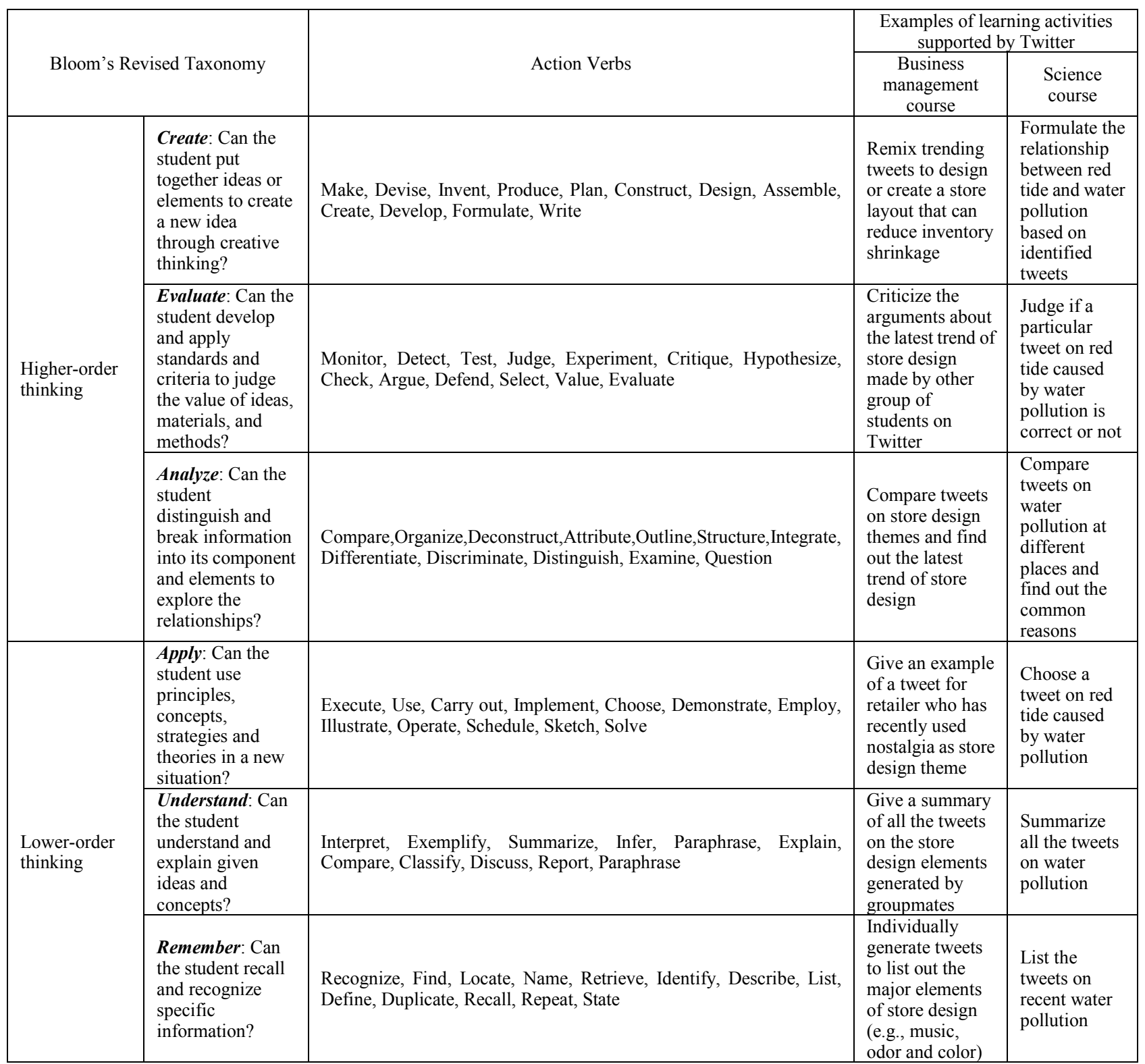

Table 2. Examples of using Twitter to achieve learning objectives of a subject "Integrated Marketing Communications"

\begin{tabular}{|l|l|}
\hline \multicolumn{1}{|c|}{ Learning objectives } & \multicolumn{1}{|c|}{ Twitter Activities } \\
\hline $\begin{array}{l}\text { Apply an IMC approach in the development of an overall advertising and } \\
\text { promotional plan; }\end{array}$ & $\begin{array}{l}\text { Add valuable data, information, resources to relevant } \\
\text { Twitter hashtags on an actual promotion of a company. }\end{array}$ \\
\hline $\begin{array}{l}\text { Analyze the changing global marketing communication environment in the digital } \\
\text { era; }\end{array}$ & $\begin{array}{l}\text { Conduct metacognitive analysis of promotional Tweets on } \\
\text { the Internet. }\end{array}$ \\
\hline $\begin{array}{l}\text { Develop insights into the characteristics of different forms of traditional and new } \\
\text { marketing communications such as advertising, sales promotions, public relations, } \\
\text { point-of-purchase communications, product placement, internet/viral marketing, } \\
\text { mobile marketing and experiential marketing; }\end{array}$ & $\begin{array}{l}\text { Discuss different marketing communication on Twitter and } \\
\text { share insights with peers on Twitter. }\end{array}$ \\
\hline $\begin{array}{l}\text { Communicate value in goods and services in real-life marketing situations; } \\
\text { Enhance their creativity, critical thinking and analytical ability through developing } \\
\text { an integrated marketing communication campaign; }\end{array}$ & $\begin{array}{l}\text { Respond to open ended questions on } \\
\text { formulation of new ideas that demonstrate a certain level of } \\
\text { conceptual knowledge. }\end{array}$ \\
\hline Develop skills in evaluating the effectiveness of a campaign. & $\begin{array}{l}\text { Moderate and host a chat on an actual promotional } \\
\text { campaign on Twitter. }\end{array}$ \\
\hline
\end{tabular}




\section{Survey Result and Discussion}

A survey was used to collect data from students to investigate students' attitudes towards using Twitter for blended learning. At the end of the semester, a well-structured questionnaire was designed based on previous research [11, 48, 49] and distributed among 100 undergraduate students in two classes in a university (i.e., Class A and B). Respondents were asked to indicate the extent to which they agree that Twitter is useful for learning, Twitter is easy to be used, Twitter can enhance collaboration and interactions among students in the class, and Twitter can motivate students to learn on a 7-point Likert scale ( $1=$ Strongly disagree, $4=$ Neutral and $7=$ Strongly agree). In addition, respondents were asked to tell us the reasons why they do not use Twitter and to provide suggestions on we can improve the use of Twitter for blended learning in the future. The overall response rate of this study is $56 \%$. Table 3 summarizes the means of survey questions of two classes.

As shown in Table 3, the means of most of the survey questions were greater than 4.0 (i.e., neutral). This showed that students were slightly agreed to majority of survey questions, suggesting that students showed positive attitudes towards using Twitter for blended learning. The findings also suggested that students might not get used to this new communication method in the educational context although social media is not new to them.
There were several common findings in the two classes. First, Q4 and Q6 got relatively the highest scores in both classes. This finding indicated that students found it easy to use Twitter for blended learning. This finding is in line with the findings of prior study, which suggested that Twitter was easy to be operated in terms of opening a new account and preparing messages for communication. Second, Q2, Q10 and Q16 also got relatively high scores in the two classes. These showed that students could complete the learning tasks with assistance of Twitter, as well as to apply and share knowledge with their classmates. This finding revealed that Twitter could assist teachers in engaging students in learning. In general, higher education institutions employ learning management systems such as Blackboard to facilitate teaching and learning. However, such learning management systems as Blackboard were criticized as platforms that engage students in group discussion in unnatural way [42]. Twitter could be an alternative channel for students to express their thoughts for knowledge exchange. As per Attwell's suggestion [3], schools may become irrelevant to the culture of discourse for youngsters if educators are unable to engage students with social media. In line with this statement, Oblinger and Hagner [36] also expressed that students need different forms of communication and they feel bored with traditional way of learning.

Table 3. The means of survey questions

\begin{tabular}{|c|c|c|c|c|}
\hline Question Types & \multicolumn{2}{|r|}{ Questions } & $\begin{array}{c}\text { Class } \\
\text { A }\end{array}$ & $\begin{array}{c}\text { Class } \\
\text { B }\end{array}$ \\
\hline \multirow{3}{*}{$\begin{array}{l}\text { Perceived } \\
\text { usefulness }\end{array}$} & Q1 & Using Twitter can improve my learning performance. & 4.71 & 4.05 \\
\hline & Q2 & Using Twitter in classroom can enable me to accomplish learning tasks more suitably. & 5.12 & 4.28 \\
\hline & Q3 & I find Twitter useful in my study. & 4.59 & 4.03 \\
\hline \multirow{3}{*}{$\begin{array}{l}\text { Perceived ease of } \\
\text { use }\end{array}$} & Q4 & Learning to use Twitter is easy for me. & 5.82 & 4.74 \\
\hline & Q5 & It is easy for me to become skillful at using Twitter. & 4.76 & 4.61 \\
\hline & Q6 & I can easily create new message and reply to others with Twitter. & 5.76 & 4.56 \\
\hline \multirow{6}{*}{$\begin{array}{l}\text { Collaboration and } \\
\text { interaction with } \\
\text { others }\end{array}$} & Q7 & The quantity of interaction with other students in this class has increased due to Twitter. & 4.41 & 3.82 \\
\hline & Q8 & The quality of interaction with other students in this class has increased due to Twitter. & 4.29 & 3.85 \\
\hline & Q9 & Twitter enhances collaborative relationships with my classmates. & 4.18 & 4.10 \\
\hline & Q10 & Twitter helps me to share my knowledge and experience with my classmates. & 5.18 & 4.18 \\
\hline & Q11 & Twitter helps me feel connected to other students in this class. & 4.47 & 4.08 \\
\hline & Q12 & I feel that I am an important part of our classroom community due to Twitter. & 4.18 & 3.92 \\
\hline \multirow{6}{*}{$\begin{array}{l}\text { Motivation and } \\
\text { facilitation of } \\
\text { learning }\end{array}$} & Q13 & Using Twitter can enhance my learning experience in general. & 4.94 & 4.05 \\
\hline & Q14 & I spend more time on learning the subject/topic because of the online activities on Twitter. & 4.47 & 3.90 \\
\hline & Q15 & The online activities on Twitter assist me in learning concepts and knowledge. & 4.82 & 4.15 \\
\hline & Q16 & $\begin{array}{l}\text { I learn more about the application of knowledge through engaging in the online activities on } \\
\text { Twitter. }\end{array}$ & 5.18 & 4.18 \\
\hline & Q17 & I am more motivated to learn by the online activities on Twitter. & 4.65 & 4.05 \\
\hline & Q18 & I reflect on my own learning because of the online activities on Twitter. & 5.00 & 4.00 \\
\hline
\end{tabular}


In contrast, Q7, Q8 and Q12 got relatively low scores in two courses. This reflected the fact that students thought the use of Twitter to facilitate interaction and connection among themselves was relatively unimportant to them. Social media have two dimensions: (1) self-presentation and (2) social presence and media richness [29]. In particular, Twitter was considered as the social medium for self-presentation, rather than social presence and media richness. It was because Twitter was micro-blogs that focus on specific content domains and text-based that merely allows a relatively simple exchange. As students could meet each other in a face-to-face manner, social presence in terms of user interaction of Twitter became relatively trivial in this context.

As shown in Table 3, the means of survey questions in Class A were in general higher than those of survey questions in Class B. The grand means of all questions in Class A and Class B were 4.81 and 4.14 respectively. This might indicate that the teacher of Class A used Twitter more skillfully than that of Class B. Learning environment is getting more challenging. Bates [5] stated that "good teaching may overcome a poor choice in the use of technology, but technology will never save poor teaching; usually it makes it worse" (p. 8). To implement social media in the educational context teachers' opinions and perceptions are important. The roles of teachers have changed. Teachers are now changing to act as facilitators to enhance student-centered learning approach. By using student-centered learning approach, students are motivated to learn and collaborate with others through the application of technologies. This approach provides learners with greater autonomy for learning [15]. Teachers are suggested to use social media tools to mediate interactions and share educational resources with students as well as to increase the participation of students in learning activities. In doing so, teachers will be able to lead students in collaborative knowledge construction and collect feedbacks from students.

Furthermore, respondents were also asked to answer two open-end questions. Frist, respondents were asked to provide the reasons of why they did not use Twitter in the class. The reasons of not using Twitter include: (1) I use Facebook rather than Twitter; (2) I found out that it was hard to continue the use of Twitter as I am not a frequent user of Twitter; (3) I seldom use Twitter; (4) There are few people who use Twitter in Hong Kong; and (5) Twitter is not commonly used in Hong Kong. It may be better for us to use other online platform, e.g. Facebook. Second, respondents were invited to provide suggestions on how Twitter can be best used in the course. Twitter was suggested to share class information (e.g., due date of assignment or short articles), articles or news related to the subject, and case study findings among students. These findings revealed that students like to use social media for sharing course information and learning materials. However, Twitter might not be the most appropriate choice as students preferred learning by using Facebook, which is the second most popular social networking site globally. These findings also suggested that the degree of familiarity is an important factor to be considered when we select a proper social networking site for educational purposes. It was suggested to use Facebook for blended learning in the future. Although Twitter has its advantages (such as being easy to use), Facebook provides a vast range of networked services and communities. Students may actively build knowledge artifacts in social interaction and collaboration, and participate in immersive network learning and connect with other learners.

\section{Further Research}

The major purpose of this paper was to find out whether Twitter, as an example of social media, was suitable to be adopted in the tertiary education. While social media are becoming more integral to classrooms and the learning content is changing because of Web 2.0 technologies, this research provides a foundation for direction for future research. More research questions are raised here for generality and applicability of social media in education. Future research on social media learning or tertiary education may address research questions, including:

- How do students create their contents in the online environment?

- How do students connect and share the information with others in such a creation process?

- How do such creation activities suggest new learning practices in terms of policies, curriculums and pedagogies?

In addition, as one of the teaching and learning tools, it is essential to recognize social media's instructional design perspective. Some relevant research questions include:

- What are the key success factors of social media learning? Is the ubiquity of social media the only factor for its consideration as a teaching and learning tool?

- What features of social media can or cannot support students in an educational context?

- What are the educators' considerations and their priorities in making decisions about the integration of social media in their curriculums?

Relatively social media is a new trend in the higher education. The following fundamental questions may be served as guidelines for future research. Does the presence of social media just reflect the change in the information technology as a kind of teaching and learning tools? Is it just a change in ways of how students learn?

\section{Conclusions}

Learning institutions have been benefited from the Internet for many years because it offers a collaborative 
learning platform to facilitate information exchange and dissemination of ideas. E-learning can complement the traditional ways of learning and facilitate the communication between educators and students as well as the collaboration among students. Nowadays, social media provide innovative ways for enhancing communication and collaboration in the education context, thus rising the learning and teaching practices onto a new level. There are two reasons of using social media in learning. First, it provides a new learning environment that enables students and teachers learn from and communicate with each other by taking the advantages of the advancement of information technology. Second, social media are able to promote student-centered learning in which students are offered a social network experience in learning as well as a personalized learning experience. Blended learning with social media have potential to alter the higher education model from traditional classroom learning mode to an asynchronous 24/7 mode [46].

In this paper, the usage of Twitter for blended learning in a university has been discussed. It was found that students generally showed positive attitudes towards the use of Twitter for learning, although they might not be used to this alternative way of learning initially. They found Twitter was easy to be used and could facilitate knowledge acquiring and sharing with their classmates. Students may publish their works personally or collaboratively on the Internet with social media tools. This can be considered as a symbolic enhancement for a current trend of "Read-Write Web" [38].

In addition, teachers play significant role in the application of social media in their classrooms. Teachers need to change their teaching practices instead of simply remaining as custodians of inert knowledge [4]. It is suggested that since both teachers and students are with different skills, they can work together in a collaborative way of teaching and learning. This concept puts emphasis on creation and dissemination of knowledge and the boundaries between teachers as knowledge creators and students as knowledge recipients become blurred considerably [23].

\section{REFERENCES}

[1] Al-Alwani, A. (2014). Information technology integration in higher education: A novel approach for impact assessment. International Journal of Emerging Technologies in Learning, 9(6): 32-36.

[2] Anderson, L.W., Krathwohl, D.R., Airasian, P.W., Bloom, B.S., Cruikshank, K.A, Pintrich, P.R. \& Mayer, R.E. (2001). A Taxonomy for Learning, Teaching and Assessing, Addison Wesley Longman, Inc,

[3] Attwell, G. (2008). Web 2.0 And The Changing Ways We Are Using Computers For Learning: What Are The Implications For Pedagogy and Curriculum. Retrieved from http://www.elearningeuropa.info/files/media/media13018.pd $\mathrm{f}$

[4] Barnes, C., \& Tynan, B. (2007). The adventures of Miranda in the brave new world: learning in a Web 2.0 millennium. Research in Learning Technology, 15(3): 189-200.

[5] Bates, T. (2005). Technology, E-Learning and Distance Education: Second Edition. Great Britain: Routledge.

[6] Borau, K., Ullrich, C., Feng, J., \& Shen, R. (2009). Microblogging for language learning: Using twitter to train communicative and cultural competence, Advances in Web Based Learning-ICWL 2009, 78-87.

[7] Button, D., Harrington, A. \& Belan, I. (2014). E-learning \& information communication technology (ICT) in nursing education: A review of the literature. Nurse Education Today, 34(10): 1311-1323.

[8] Carpenter, J.P. \& Krutka, D.G. (2014). Engagement through microblogging: educator professional development via Twitter. Professional Development in Education, 41(4): 707-728.

[9] Dabbagh, N. \& Kitsantas, A. (2012). Personal learning environments, social media, and self-regulated earning: A natural formal for connecting formal and informal learning. Internet and Higher Education, 15(1): 3-8.

[10] Dabbagh, N., \& Reo, R. (2011). Impact of Web 2.0 on higher education. In D. W. Surry, T. Stefurak, \& R. Gray (Eds.), Technology Integration in Higher Education: Social and Organizational Aspects (pp. 174-187). Hershey, PA: IGI Global.

[11] Davis, F.D. (1989). Perceived usefulness, perceived ease of use, and user acceptance of information technology. MIS Quarterly, 13(3): 319-339.

[12] Deed, C., \& Edwards, A. (2011). Unrestricted student blogging: Implications for active learning in a virtual text-based environment, Active Learning in Higher Education, 12(1), 11-21.

[13] Degroot, J.M., Young, V.J. \& Vanslette, S.H. (2015). Twitter use and its effects on student perception of instructor credibility. Communication Education, 25:1-19.

[14] Deng, L., \& Yuen, A.H.K. (2011). Towards a framework for educational affordances of blogs, Computers \& Education, 56(2), 441-451.

[15] Downes, S. (2005). E-learning 2.0. eLearn Magazine, 2005(10): 1 .

[16] Dron, J. (2007). Control and Constraint in E-Learning: Choosing When to Choose. Hershey, PA: Idea Group.

[17] Dunlap, J.C., \& Lowenthal, P.R. (2009). Tweeting the night away: Using Twitter to enhance social presence, Journal of Information Systems Education, 20(2), 129-135.

[18] Dyson, B., Vickers, K., Turtle, J., Cowan, S. \& Tassone, A. (2015). Evaluating the use of Facebook to increase student engagement and understanding in lecture-based classes. Higher Education, 69(2): 303-313.

[19] Evans, C. (2014). Twitter for teaching: Can social media be used to enhance the process of learning? British Journal of Educational Technology, 45(5): 902-915.

[20] Grosch, M., Berger, R., Gidion, G. \& Romeo, M. (2014). Which media services do students use in fact? Results of an international empirical survey. Procedia - Social and Behavioral Sciences, 141: 795-806. 
[21] Hazari, S., North, A., \& Moreland, D. (2009). Investigating pedagogical value of wiki technology. Journal of Information Systems Education, 20(2): 187-198.

[22] Huang, T. C., Huang, Y.M., \& Yu, F.Y. (2011). Cooperative weblog learning in higher education: Its facilitating effects on social interaction, time lag, and cognitive load, Educational Technology \& Society, 14(1), 95-106.

[23] Huijser, H. (2008). Exploring the educational potential of social networking sites: the fine line between exploiting opportunities and unwelcome imposition. Studies in Learning, Evaluation, Innovation and Development, 5(3): 45-54.

[24] Irwin, C., Ball, L., Desbrow, B., \& Leveritt, M. (2012). Students' perceptions of using Facebook as an interactive learning resource at university, Australasian Journal of Educational Technology, 28(7), 1221-1232.

[25] Junco, R., Heiberger, G., \& Loken, E. (2011). The effect of Twitter on college student engagement and grades, Journal of Computer Assisted Learning, 27(2), 119-132.

[26] Jung, I. \& Lee, Y. (2015). YouTube acceptance by university educators and students: A cross-cultural perspective. Innovations in Education and Teaching International, 52(3): 243-253.

[27] Kabilan, M.K., Ahmad, N., \& Abidin, M.J.Z. (2010). Facebook: An online environment for learning of English in institutions of higher education? The Internet and Higher Education, 13(4), 179-187.

[28] Kamal Hayder Kazmi, S. (2015). Research corner Information technology offering key role for education growth. Pakistan \& Gulf Economist, April 5, 34(13).

[29] Kaplan, A.M. \& Haenlein, M. (2010). Users of the world, unite! The challenges and opportunities of social media. Business Horizons, 53(1): 59-68.

[30] Kassens-Noor, E. (2012). Twitter as a teaching, practice to enhance active and informal learning in higher education: The case of sustainable tweets. Active Learning in Higher Education, 13(1): 9-21

[31] Li, J. \& Greenhow, C. (2015). Scholars and social media: tweeting in the conference backchannel for professional learning. Educational Media International, 52(1), 1-14.

[32] Luo, T. (2014). Enabling microblogging-based peer feedback in face-to-face classrooms. Innovations in Education and Teaching International, 1-11.

[33] McCarthy, J. (2010). Blended learning environments: Using social networking sites to enhance the first year experience, Australasian Journal of Educational Technology, 26(6), 729740 .

[34] Milošević, I., Živković, D., Arsić, S. \& Manasijević, D. (2015). Facebook as virtual classroom - Social networking in learning and teaching among Serbian students. Telematics and Informatics, 32(4): 576-585.

[35] Miri, B., David, B. C., \& Uri, Z. (2007). Purposely Teaching for the promotion of higher-order thinking skills: A case of critical thinking. Research in Science Education, 37(4): 353-369.

[36] Oblinger, D. G., \& Hagner, J. L. (2005). Educating the Net Generation: EDUCAUSE.
[37] Ophus, J.D., \& Abbitt, J.T. (2009). Exploring the potential perceptions of social networking systems in university courses, Journal of Online Learning and Teaching, 5(4), 639648 .

[38] O'Reilly, T. (2005). What Is Web 2.0: Design Patterns and Business Models for the Next Generation of Software. O'Reilly Media. Retrieved from http://www.oreillynet.com/p ub/a/oreilly/tim/news/2005/09/30/what-is-web-20.html

[39] Peeraer, J. \& Van Petegem, P. (2015). Integration or transformation? Looking in the future of Information and Communication Technology in education in Vietnam. Evaluation and Program Planning, 48: 47-56.

[40] Rambe, P. (2012). Critical discourse analysis of collaborative engagement in Facebook postings, Australasian Journal of Educational Technology, 28(2), 295-314.

[41] Razep, E. \& Abel, U. (2014). Acceptance factors and current level of use of Web 2.0 technologies for learning in higher education: A case study of two countries. International Journal of Advanced Computer Science and Applications, 5(5): 9-14.

[42] Siemens, G. (2005). Connectivism: A learning theory for the digital age. International Journal of Instructional Technology and Distance Learning, 2(1): 3-10.

[43] Sim, J.W.S., \& Hew, K.F. (2010). The use of weblogs in higher education settings: A review of empirical research, Educational Research Review, 5(2), 151-163.

[44] Smith, S. D. \& Caruso, J. B. (2010). The ECAR study of undergraduate students and information technology, 2010. EDUCAUSE Center for Applied Research (ECAR), Retrieved fromhttp://www.educause.edu/ecar

[45] Smyth, R. (2010). Equity and information communication technology in education. British Journal of Educational Technology, 41(3): 58-58.

[46] Thompson, J. (2007). Is Education 1.0 Ready for Web 2.0 Students? Journal of Online Education, 3(4): 5.

[47] Thoms, B. \& Eryilmaz, E. (2015). Introducing a twitter discussion board to support learning in online and blended learning environments. Education and Information Technologies, 20(2): 265-283.

[48] Top, E. (2012). Blogging as a social medium in undergraduate courses: Sense of community best predictor of perceived learning. The Internet and Higher Education, 15(1): $24-28$

[49] Van Wyk, M.M. (2013). Exploring students perceptions of blogs during teaching practice placements. Mediterranean Journal of Social Sciences, 4(14): 525-533.

[50] Vogel-Walcutt, J.J., Gebrim, J.B., Bowers, C., Carper, T.M. \& Nicholson, D. (2011). Cognitive load theory vs. constructivist approaches: Which bets leads to efficient, deep learning? Journal of computer assisted learning, 27(2): 133-145.

[51] Zheng, B., Niiya, M. \& Warschauer, M. (2015). Wikis and collaborative learning in higher education. Technology, Pedagogy and Education, 6(1): 1-18. 